\title{
Perbedaan Tingkat Optimisme pada Mahasiswa Semester Awal dan Mahasiswa Semester Akhir Strata Satu Fakultas Kedokteran
}

\author{
Majesty P. Umboh, ${ }^{1}$ Cicilia Pali, $^{2}$ Lydia E. V. David ${ }^{2}$
}

\author{
${ }^{1}$ Program Studi Pendidikan Dokter Fakultas Kedokteran Universitas Sam Ratulangi Manado \\ ${ }^{2}$ Bagian Psikologi Fakultas Kedokteran Universitas Sam Ratulangi Manado \\ Email: majestyu24@gmail.com
}

\begin{abstract}
This study was aimed to obtain the difference in optimism between the first and the final semester students of Faculty of MedicineThis was an analytical and observational study. Subjects were students of the first and the final semester of Faculty of Medicine Sam Ratulangi University Manado obtained by using total sampling technique. The instrument of this study was Alat ukur yang digunakan ialah kuesioner LOT-R questionnaire consisting of 10 items. Data were analyzed by using the Mann-Whitney test that obtained a p-value of 0.001 for the difference in optimism level. In conclusion, there was a significant difference in the optimism level between the students of the first and the final semesters of Faculty of Medicine
\end{abstract}

Keywords: optimism, medical students

\begin{abstract}
Abstrak: Penelitian ini bertujuan untuk mengetahui adanya perbedaan tingkat optimisme pada mahasiswa semester awal dan mahasiswa semester akhir Fakultas Kedokteran. Jenis penelitian ialah analitik observasional. Subjek penelitian berjumlah 100 mahasiswa semester awal dan 100 mahasiswa semester akhir Fakultas Kedokteran Universitas Sam Ratulangi Manado yang diperoleh dengan menggunakan teknik total sampling. Alat ukur yang digunakan ialah kuesioner LOT-R (10 aitem). Data dianalisis secara statistik menggunakan uji Mann-Whitney yang mendapatkan nilai $\mathrm{p}=0,001$ untuk perbedaan tingkat optimisme. Simpulan penelitian ini ialah terdapat perbedaan tingkat optimisme pada mahasiswa semester awal dan mahasiswa semester akhir Fakultas Kedokteran.
\end{abstract}

Kata kunci: optimisme, mahasiswa Falultas Kedokteran

\section{PENDAHULUAN}

Mahasiswa merupakan individu yang sedang melaksanakan studi di perguruan tinggi. Secara aktif, mahasiswa mengembangkan potensinya dengan melakukan pembelajaran, pencarian kebenaran ilmiah, dan/atau penguasaan, pengembangan, dan pengamalan suatu cabang ilmu pengetahuan dan/atau teknologi untuk menjadi ilmuwan, intelektual, praktisi, dan/atau profesional yang berbudaya. ${ }^{1}$ Menjadi mahasiswa, memiliki banyak tuntutan dalam proses pembelajarannya untuk akhirnya disebut berkompeten dan mendapat gelar sarjana. $^{2}$
Mahasiswa kedokteran yang sedang studi nantinya akan menjadi dokter. Dokter adalah salah satu tenaga kesehatan yang berperan sangat penting dalam masalah kesehatan. Mulai dari mencanangkan program kesehatan sampai pada penanganan penyakit pada masyarakat. ${ }^{3}$ Dokter memiliki tanggung jawab yang besar terhadap kesehatan masyarakat. Jika menjadi seorang tenaga kesehatan yang berkompeten, seorang dokter harus mengikuti serangkaian proses pendidikan, yaitu dimulai dengan kuliah untuk mendapatkan gelar sarjana kedokteran, dilanjutkan dengan pendidikan profesi dokter serta telah 
memenuhi syarat dan dinyatakan lulus pada ujian kompetensi dokter Indonesia. ${ }^{4}$

Dalam proses pembelajaran mahasiswa kedokteran, mengalami banyak hambatan dalam mencapai gelar dokter. Hambatan yang terjadi dapat mendorong suatu keyakinan akan hasil yang tidak baik bagi mahasiswa kedokteran. ${ }^{5}$

Oleh karena mahasiswa kedokteran memiliki banyak tantangan dibutuhkan semangat untuk mengerjakan studi sampai selesai. Salah satu aspek yang harus dimiliki seorang mahasiswa kedokteran yaitu optimisme. Optimisme adalah suatu keyakinan yang menyeluruh akan suatu hal, melihat sesuatu sebagai hal baik dan mudah memberi makna positif bagi diri sendiri. ${ }^{6}$ Optimisme merupakan suatu faktor yang sangat berpengaruh dalam kehidupan individu. ${ }^{7}$ Seseorang yang optimis akan memandang kegagalan sebagai proses pengembangan diri yang akan memberikan hal yang baik dimasa depan. ${ }^{8}$

Menurut Schulman seseorang yang optimis akan cenderung terkait dengan pencapaian prestasi akademik yang tinggi di perguruan tinggi dan meningkatnya produktivitas kerja. ${ }^{8,9}$ Optimisme menjadi salah satu faktor penentu dalam keberhasilan seseorang dalam mencapai tujuannya. ${ }^{8}$ Optimisme sebagai konstruk psikologi yang memiliki pengaruh positif pada kehidupan individu penting untuk dimiliki mahasiswa kedokteran guna mengatasi hambatan-hambatan dalam dunia pendidikan kedokteran. ${ }^{6}$

Menurut survei awal pada mahasiswa semester awal dan semester akhir terlihat adanya perbedaan tingkat optimisme. Pada mahasiswa semester awal, keyakinan untuk menyelesaikan pendidikan kedokteran tepat waktu sangat besar. Pada mahasiswa semester akhir, keyakinan untuk menyelesaikan pendidikan kedokteran tepat waktu sangat kecil dikarenakan tuntutan akademik dan non-akademik yang semakin berat. Oleh karena itu, perlu adanya penelitian untuk mengetahui seberapa besar peran optimisme dalam mempengaruhi aspekaspek lain pada diri mahasiswa kedokteran yang juga berkontribusi membantu maha- siswa keluar dari permasalahan yang ada pada bidang profesinya.

\section{METODE PENELITIAN}

Penelitian ini menggunakan pendekatan kuantitatif dalam bentuk penelitian komparatif untuk menguji apakah dua sampel yang diteliti terdapat perbedaan terkait suatu aspek yang diteliti yaitu tingkat optimisme. Jenis penelitian ini ialah analitik observasional dengan desain potong lintang.

Data yang diperoleh diolah secara bivariat dan univariat dengan menggunakan SPSS, kemudian data hasil penelitian diuji normalitasnya untuk menentukan jenis uji lanjut. Uji Mann-Whitney bertujuan untuk menguji signifikansi beda rerata dua kelompok, adanya perbedaan dua kelompok/sampel data yang independen yaitu tingkat optimisme pada mahasiswa semester awal dan mahasiswa semester akhir Program Studi Kedokteran Umum Fakultas Kedokteran Universitas Sam Ratulangi

\section{HASIL PENELITIAN}

Tabel 1 memperlihatkan bahwa baik untuk semester awal maupun semester akhir, subyek dengan tingkat optimisme sedang yang terbanyak (58\% vs $41 \%)$ diikuti tingkat optimisme tinggi (36\% vs $31 \%$ ) dan tingkat optimisme rendah (6\% vs $28 \%$ ).

Tabel 2 menunjukkan hasil analisis deskriptif kedua kelompok subyek penelitian. Pada semester awal nilai rerata skoring kuesioner LOT-R ialah 17, nilai tengah 18 , nilai yang paling banyak diperoleh 18 , nilai minimum 12 , dan nilai maksimum 23. Pada semester akhir nilai rerata ialah 16 , nilai tengah 16 , nilai yang paling banyak diperoleh 13 , nilai minimum 11, dan nilai maksimum 23. Perbedaan yang cukup besar terdapat pada nilai modus, yaitu pada mahasiswa semester awal nilai yang paling banyak ialah 18 (termasuk dalam tingkat optimisme sedang) dan pada mahasiswa semester akhir nilai yang paling banyak ialah 13 (termasuk dalam tingkat optimisme rendah).

Tabel 3 memperlilhatkan persentase 
tingkat optimisme tinggi yang sama pada laki-laki dan perempuan $(36 \%)$; persentase tingkat optimisme sedang paling banyak pada perempuan $(58,7 \%)$; dan persentase tingkat optimisme rendah paling banyak pada laki-laki (8\%).

Tabel 4 memperlihatkan persentase tingkat optimisme tinggi lebih banyak pada perempuan $(30,8 \%)$; persentase tingkat optimisme sedang paling banyak pada perempuan $(50,7 \%)$; dan persentase tingkat optimisme rendah paling banyak pada laki- laki $(37,1 \%)$.

Tabel 5 memperlihatkan persentase tingkat optimisme tertinggi berada pada subyek penelitian berusia 19 tahun $(57,1 \%)$ dan terendah pada subyek penelitian berusia 17 tahun $(29,3 \%)$. Persentase tingkat optimisme sedang paling banyak pada usia 16 tahun $(66,6 \%)$ dan paling sedikit pada usia 19 tahun $(35,7 \%)$. Persentase tingkat optimisme rendah paling banyak pada usia 18 dan 19 tahun $(7,2 \%)$ dan paling sedikit pada usia 16 tahun $(0 \%)$..

Tabel 1. Hasil kuesioner LOT-R pada semester awal dan semester akhir

\begin{tabular}{ccccc}
\hline Tingkat optimisme & \multicolumn{2}{c}{ Semester awal } & \multicolumn{2}{c}{ Semester akhir } \\
\cline { 2 - 5 } & $\mathrm{J}$ & $\mathrm{P}$ & $\mathrm{J}$ & $\mathrm{P}$ \\
\hline Rendah & 6 & $6 \%$ & 28 & $28 \%$ \\
Sedang & 58 & $58 \%$ & 41 & $41 \%$ \\
Tinggi & 36 & $36 \%$ & 31 & $31 \%$ \\
\hline
\end{tabular}

J: Jumlah, P: Persentase

Tabel 2. Statistik deskriptif hasil kuesioner LOT-R pada semester awal dan semester akhir

\begin{tabular}{cccccc}
\hline Subyek & Mean & Median & Modus & Maks. & Min. \\
\hline Semester awal & 17 & 18 & 18 & 23 & 12 \\
Semester akhir & 16 & 16 & 13 & 23 & 11 \\
\hline
\end{tabular}

Tabel 3. Tingkat optimisme berdasarkan jenis kelamin pada semester awal

\begin{tabular}{ccccc}
\hline Tingkat optimisme & \multicolumn{2}{c}{ Laki-laki } & \multicolumn{2}{c}{ Perempuan } \\
\hline & $\mathrm{J}$ & $\mathrm{P}$ & $\mathrm{J}$ & $\mathrm{P}$ \\
Tinggi & 9 & $36 \%$ & 27 & $36 \%$ \\
Sedang & 14 & $56 \%$ & 44 & $58,7 \%$ \\
Rendah & 2 & $8 \%$ & 4 & $5,3 \%$ \\
Total & 25 & 100 & 65 & 100 \\
\hline
\end{tabular}

J: Jumlah, P: Persentase

Tabel 4. Tingkat optimisme berdasarkan jenis kelamin pada semester akhir.

\begin{tabular}{ccccc}
\hline Tingkat optimisme & \multicolumn{2}{c}{ Laki-laki } & \multicolumn{2}{c}{ Perempuan } \\
\hline & $\mathrm{J}$ & $\mathrm{P}$ & $\mathrm{J}$ & $\mathrm{P}$ \\
Tinggi & 9 & $25,7 \%$ & 20 & $30,8 \%$ \\
Sedang & 13 & $37,1 \%$ & 33 & $50,7 \%$ \\
Rendah & 13 & $37,1 \%$ & 12 & $18,5 \%$ \\
Total & 35 & 100 & 65 & 100 \\
\hline
\end{tabular}

J: Jumlah, P: Persentase 
Tabel 5. Tingkat optimisme berdasarkan usia pada mahasiswa semester awal

\begin{tabular}{ccccccccc}
\hline Tingkat optimisme & \multicolumn{1}{c}{$\mathbf{1 6}$ tahun } & \multicolumn{2}{c}{$\mathbf{1 7}$ tahun } & \multicolumn{2}{c}{$\mathbf{1 8}$ tahun } & \multicolumn{2}{c}{19 tahun } \\
\hline & $\mathrm{J}$ & $\mathrm{P}$ & $\mathrm{J}$ & $\mathrm{P}$ & $\mathrm{J}$ & $\mathrm{P}$ & $\mathrm{J}$ & $\mathrm{P}$ \\
Tinggi & 1 & $33,4 \%$ & 12 & $29,3 \%$ & 15 & $35,7 \%$ & 8 & $57,1 \%$ \\
Sedang & 2 & $66,6 \%$ & 27 & $65,8 \%$ & 24 & $57,1 \%$ & 5 & $35,7 \%$ \\
Rendah & - & - & 2 & $4,9 \%$ & 3 & $7,2 \%$ & 1 & $7,2 \%$ \\
Total & 3 & 100 & 41 & 100 & 42 & 100 & 14 & 100 \\
\hline
\end{tabular}

$\mathrm{J}=\mathrm{Jumlah}$ subyek $\mathrm{P}=$ presentase

Tabel 6. Tingkat optimisme berdasarkan usia pada mahasiswa semester akhir

\begin{tabular}{ccccccccccccc}
\hline $\begin{array}{c}\text { Tingkat } \\
\text { optimisme }\end{array}$ & $\mathbf{1 8}$ tahun & $\mathbf{1 9}$ tahun & $\mathbf{2 0}$ tahun & $\mathbf{2 1}$ tahun & 22 tahun & 23 tahun \\
\hline & $\mathrm{J}$ & $\mathrm{P}$ & $\mathrm{J}$ & $\mathrm{P}$ & $\mathrm{J}$ & $\mathrm{P}$ & $\mathrm{J}$ & $\mathrm{P}$ & $\mathrm{J}$ & $\mathrm{P}$ & $\mathrm{J}$ & $\mathrm{P}$ \\
Tinggi & 1 & $33,3 \%$ & 2 & $25 \%$ & 11 & $32,3 \%$ & 12 & $26,1 \%$ & 3 & $60 \%$ & - & - \\
Sedang & 1 & $33,3 \%$ & 3 & $37,5 \%$ & 13 & $38,3 \%$ & 24 & $52,2 \%$ & 2 & $40 \%$ & 1 & $50 \%$ \\
Rendah & 1 & $33,3 \%$ & 3 & $37,5 \%$ & 10 & $29,4 \%$ & 10 & $21,7 \%$ & - & - & 1 & $50 \%$ \\
Total & 3 & 100 & 10 & 100 & 34 & 100 & 46 & 100 & 5 & 100 & 2 & 100 \\
\hline
\end{tabular}

$\mathrm{J}=\mathrm{Jumlah}$ subyek $\%=$ presentase

Tabel 6 memperlihatkan hasil tingkat optimisme dengan menggunakan LOT-R berdasarkan usia pada mahasiswa semester akhir. Data yang diperoleh ialah pada usia 18 tahun, jumlah subyek untuk masingmasing tingkat optimisme sama banyak $(33,3 \%)$. Pada usia 19 tahun, subyek dengan tingkat optimisme tinggi (25\%) lebih sedikit dibandingkan subyek dengan tingkat optimisme sedang dan rendah (masing-masing 37,5\%). Pada usia 20 tahun, jumlah subyek dengan optimisme sedang yang paling tinggi yaitu 13 subyek (38,3\%). Pada usia 21 tahun, jumlah subyek dengan optimisme sedang yang paling tinggi yaitu 24 subyek $(52,2 \%)$. Pada usia 22 tahun, jumlah subyek dengan tingkat optimisme tinggi yaitu 3 subyek (60\%), jumlah subyek dengan tingkat optimisme sedang 2 subyek (40\%) dan tidak ada subyek dengan tingkat optimisme rendah. Pada usia 23 tahun, didapatkan jumlah subyek dengan tingkat optimisme sedang dan rendah sama banyak, masingmasing 1 subyek (50\%).

Hasil uji normalitas data mendapatkan nilai $\mathrm{p}=0,027$ untuk semester awal dan $\mathrm{p}=0,000$ untuk semester akhir $(<0,05)$, yang berarti bahwa data penelitian tidak terdistribusi normal. Oleh karena itu, untuk uji lanjut digunakan uji Mann-Whitney yang mendapatkan nilai $p=0,001<0,05$; hasil ini menunjukkan adanya perbedaan tingkat optimisme antara mahasiswa semester awal dan semester akhir.

\section{BAHASAN}

Setelah dilakukan analisis data kuantitatif dengan menggunakan bantuan SPSS versi 23, didapatkan adanya perbedaan tingkat optimisme antara mahasiswa semester awal dan mahasiswa semester akhir. Hal ini didukung oleh penelitian yang dilakukan di salah satu universitas di Indonesia, yang menyebutkan bahwa mahasiswa cenderung memiliki tingkat optimisme yang tinggi. ${ }^{10}$ Sebagian besar mahasiswa memiliki optimisme yang tinggi dalam proses pendidikan sehingga mahasiswa mampu untuk mempercayai penyebab baik bersifat menetap (permanence), memberikan penjelasan spesifik ketika menghadapi peristiwa buruk (pervasiveness) dan meyakini suatu peristiwa disebabkan oleh faktor dalam diri (personalization). ${ }^{8,9}$ Namun pada penelitian ini ter- 
lihat adanya perbedaan tingkat optimisme antara mahasiswa semester awal dan semester akhir. Mahasiswa semester akhir cenderung memiliki tingkat optimisme yang lebih rendah dibandingkan mahasiswa semester awal. Hal ini selaras dengan penelitian oleh Ningrum ${ }^{11}$ yang menyatakan bahwa tingkat optimisme pada mahasiswa semester akhir yang sedang menyelesaikan tugas akhir cenderung rendah. Hal ini dapat dipengaruhi oleh beberapa faktor yaitu faktor internal dan faktor eksternal. Mahasiswa semester akhir memiliki tanggung jawab terhadap studi lebih besar dibandingkan mahasiswa semester awal. Mahasiswa semester akhir dituntut dengan penyelesaian tugas akhir (skripsi) dan segera setelah itu akan dihadapkan dengan proses pendidikan selanjutnya, yaitu pendidikan profesi dokter. Hal ini akan memengaruhi pandangan mahasiswa semester akhir akan masa depannya. Adapun faktorfaktor yang dapat memengaruhi tingkat optimisme seseorang yaitu faktor internal, yakni faktor yang berasal dari diri sendiri seperti pengalaman, self-esteem dan selfefficacy. ${ }^{8,9,12}$ Faktor lainnya ialah fak-tor eksternal, yaitu faktor yang berasal dari luar diri seorang individu, seperti faktor keluarga, sosial ekonomi, dan media. ${ }^{12,13}$ Faktor-faktor ini memengaruhi tinggi atau rendahnya tingkat optimisme seseorang.

Subjek penelitian yang memiliki tingkat optimisme tinggi pada kedua populasi diwawancara dengan pertanyaan mengenai faktor yang memengaruhi tingkat optimisme yang diperoleh masing-masing. Pada mahasiswa semester awal yang memiliki tingkat optimisme tinggi cenderung dipengaruhi oleh faktor eksternal seperti keluarga, sosial ekonomi, dan media. Pada mahasiswa semester awal, support dari orang tua dan lingkungan di sekitar mereka sangat mendukung proses pembelajaran di Fakultas Kedokteran. Namun, mahasiswa semester awal merasa bahwa dirinya kurang mampu menjalani proses pendidikan yang ada di Fakultas Kedokteran. Dapat dilihat bahwa yang berperan pada tingkat optimisme mahasiswa semester awal ialah faktor eksternal. Mahasiswa semester akhir cenderung dipengaruhi oleh faktor internal seperti, self-esteem, selfefficacyI, dan pengalaman diri. Mahasiswa semester akhir yang optimis merasa bahwa dirinya mampu dan yakin untuk menyelesaikan studinya di Fakultas Kedokteran. Meskipun banyak tekanan dan tuntutan studi namun mahasiswa semester akhir meyakini bahwa semuanya akan terlewati dan bisa meraih cita-cita sebagai seorang dokter. Mahasiswa semester akhir memiliki rasa harga diri dan percaya diri yang tinggi dalam proses menyelesaikan studi di Fakultas Kedokteran, segala proses dan keberhasilan yang telah dilalui oleh mahasiswa semester akhir semakin mendo-rong dirinya untuk sukses menjalani proses pendidikan selanjutnya. Dapat dilihat bahwa yang berperan pada tingkat optimisme mahasiswa semester akhir ialah faktor internal. Hal ini menunjukkan adanya perbedaan faktor yang memengaruhi tingkat optimisme pada mahasiswa semester awal dan pada mahasiswa semester akhir Fakultas Kedokteran. Mahasiswa semester awal cenderung dipengaruhi oleh faktor eksternal dan mahasiswa semester akhir cenderung dipengaruhi oleh faktor internal.

Peranan optimisme sangat penting dalam kesuksesan studi seseorang. ${ }^{14}$ Pada penelitian ini didapatkan bahwa mahasiswa semester awal dan mahasiswa semester akhir strata satu di Fakultas Kedokteran memiliki tingkat optimisme baik dipengaruhi oleh faktor internal maupun eksternal. Mahasiswa Fakultas Kedokteran memiliki nilai optimisme yang baik yang akan memengaruhi capaian prestasi belajar dan kesuksesan dalam menjalani proses menjadi tenaga medis yang profesional.

\section{SIMPULAN}

Terdapat perbedaan bermakna pada tingkat optimisme antara mahasiswa semester awal dan mahasiswa semester akhir Fakultas Kedokteran. Baik mahasiswa semester awal maupun mahasiswa semester akhir lebih banyak memiliki tingkat optimisme sedang.

Hasil penelitian ini dapat menjadi masukan bagi institusi baik sebagai refe- 
rensi penelitian selanjutnya maupun sebagai bahan ajar di institusi terkait. Penelitian ini kiranya dapat menjadi masukan dan pengetahuan bagi mahasiswa semester awal dan semester akhir untuk mengetahui tingkat optimisme masing-masing. Bagi mahasiswa dengan tingkat optimisme rendah agar mengembangkan diri dan mengubah pandangan akan masa depan, karena hal ini berperan penting dalam pencapaian keberhasilan studi seseorang.

\section{Konflik Kepentingan}

Penulis menyatakan tidak terdapat konflik kepentingan dalam studi ini.

\section{DAFTAR PUSTAKA}

1. Republik Indonesia. Undang-Undang Nomor 12 Tentang Pendidikan Tinggi. Lembaran Negara RI Tahun 1992, No. 115. Sekretariat Negara. Jakarta, 2012.

2. Poerwadarminta WJS. Kamus Umum Bahasa Indonesia (3th ed). Jakarta: Balai Pustaka, 2005.

3. Majelis Kehormatan Etik Kedokteran Indonesia Ikatan Dokter Indonesia. Kode Etik Kedokteran Indonesia dan Pedoman Pelaksanaan Kode Etik Kedokteran Indonesia. Jakarta: Konsil Kedokteran Indonesia, 2002.

4. Konsil Kedokteran Indonesia. Standar Pendidikan Profesi Dokter Indonesia (2nd ed). Jakarta: Konsil Kedokteran Indonesia, 2012.

5. Musabiq S, Meinarno EA. Optimisme sebagai prediktor psikologis pada mahasiswa kebidanan. Jurnal Kedokteran dan Kesehatan. 2017;13(2):134-43.

6. Seligman MEP. Learned Optimism. New York: Simon \& Schuster Inc, 1990.

7. Youssef CM, Luthans F. Positive organizational behavior in the workplace: The impact of hope, optimism, and resilience. Journal of Management. 2007; 33(5):774-800.

8. Compton WC. Hoffman E. Positive Psychology. Wadsworth Cengage Learning, 2013.

9. Peterson C, Seligman MEP. Character Strength and Virtues. Oxford: American Psychological Association, 2004.

10. Thanoesya R, Syahniar S, Ifdil I. Konsep diri dan optimisme mahasiswa dalam proses penulisan skripsi. JPPI. 2016;2(2):58-61.

11. Ningrum DW. Hubungan antara optimisme dan coping stres pada mahasiswa UEU yang sedang menyusun skripsi. Jurnal Psikologi. 2011;9(1):41-7.

12. Wimberly SR, Carver CS, Antoni MH. Effects of optimism, interpersonal relationships, and distress on psychosexual well-being. Psychol Health. 2008;23(1):57-72.

13. Nasa AF. Hubungan antara resilensi dan optimisme pada mahasiswa yang berasal dari keluarga miskin [Skripsi]. Depok: Universitas Indonesia; 2012.

14. Putri AR, Frieda NR. Self esteem dan optimisme raih kesuksesan karir pada fresh graduate Fakultas Teknik Universitas Diponegoro. Empati. 2015;4(4): 15-9. 